\title{
IMPORTANCE OF NURTURING ENTREPRENEURSHIP SKILLS IN STUDENTS
}

\author{
Kshitij Shinghal, Amit Saxena \\ Dept. of E\&C Engg., Moradabad Institute of Technology \\ Moradabad, U.P., India
}

\begin{abstract}
As India is a developing country it is very important to promote and encourage entrepreneurial activities and startups among students to contribute and build strong economy of the nation. There is a direct relationship between the number of startups, enterprises set up and the economic development of a country. Everyone including government, persons from industries, academicians, technocrats etc. have started recognizing the importance of promoting setup of new enterprises and startups in social and economic growth as well as generation of employment. Further the students especially from science and technology background has significant contribution in developing technologies that can be developed into products and foster the economic need of society. Therefore, it is required to encourage more and more students to develop and start their own startups. Nurturing entrepreneurship skills in students right in the beginning can help them to develop strong entrepreneurial mindset and inexorable power to think, take decisions, identify opportunities and develop skillset to become entrepreneurs of tomorrow.
\end{abstract}

KEYWORDS: entrepreneurship, startups, entrepreneurial mindset,

\section{INTRODUCTION}

The role of faculty at higher education level is not only to impart knowledge to the students bur also to imbibe skillset in the students so as they are able to succeed in the complex rapidly changing world of today. One of the important skillset which can be developed or taught to the students is entrepreneurship skills. Generally, it is observed that the young students are very bright and they are bubbling with new and fresh innovative ideas. Once equipped with entrepreneurial mindset as a part of education will give students orientation for creative thinking, thinking out of the box solution to establish startups and develop new innovative ideas [1-4].

It is a common misunderstanding that entrepreneurship means establishing a business setup. And many times during entrepreneurship workshops or training programs students do ask "why do you want me to do business, I don't want to start company", but actually entrepreneurship does not mean that you have to start a business if you learn entrepreneurial skills. In real entrepreneurship is the way of living, it is a behavior, attitude or a mindset, and a behavior can always be learned or unlearned.

Entrepreneurial behavior enhance the value of knowledge, by developing a creative thinking among the students and developing a creative thinking in him to convert his knowledge in to real life practical solutions. Key entrepreneurial skills are shown in figure 1. An entrepreneur must have abilities such as taking initiative, problem-solving, flexibility, adaptability, self-awareness, and resilience. It is the high time to recognize the importance of imparting these skills to the students. Students can be made to acquire these skills by attending events, courses, workshops, and training programs which impart entrepreneurship skills.

It is very important to impart these entrepreneurial skills to the students in early age of education. Because as early they acquire these skills better equipped they will be to take right decisions in their future life. 


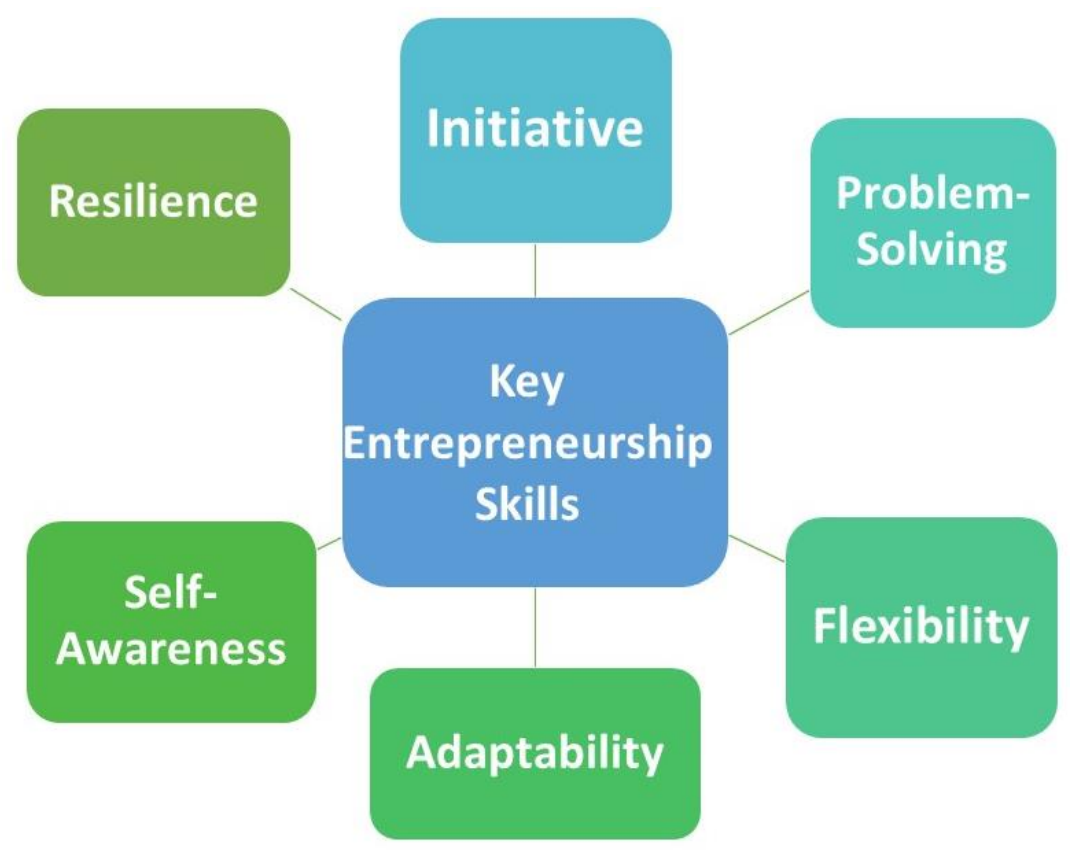

Figure 1 Key entrepreneurial skills

\section{Role OF Higher EduCATION IN NURTURing EnTREPRENEURShiP SKILLS}

Entrepreneurial skills, as a part of life skills, can be inculcated from various dimensions but the best way is through educational institutions. Educators and faculty members can help motivate students to grow with an enterprising spirit so that they can accept new challenges, find opportunities, develop management capability, and overcome external/internal barriers within the business environment. An educator has an important role to develop and prepare the students with entrepreneurial mindset so that they are ready to take up the challenges with their newly acquired entrepreneurial skillset

The most important thing which needs to be incorporated in curriculum to develop entrepreneurial mindset in students is to make the teaching learning methodology more participative in nature, students should be able to see value in the topics being taught to them. Further the teaching should involve more of quizzes, case studies, simulation games, group discussions etc. educator must include practical approach how developing entrepreneurial mindset will help in strengthening the economy of country. Incorporating such techniques will not only increase the interest of the students but will also develop required skill set in him in natural learning process. Similarly in this process the faculty teaching entrepreneurial mindset will also learn entrepreneurial behavior.

Entrepreneurially minded people are blessed with the unique ability to

Identify an idea or an opportunity, evaluate it, and exploit as shown in figure 2 as already discussed entrepreneurial mindset is a behavior, once acquired the people with entrepreneurial mindset will use it in every sphere of life, may it be social, economic or any other place.

Building entrepreneurship skills include imparting a mix of technical skills, management skills, and personal maturity skills - such as self-awareness, accountability, creativity and emotional stability - all of which equips students with the ability to take risks, and become innovative, change-oriented, and persistent individuals. Developing the right set of entrepreneurship skills help students recognize the social and economic opportunities and act upon them, thus maximizing their chance for experiential learning [5-7]. 


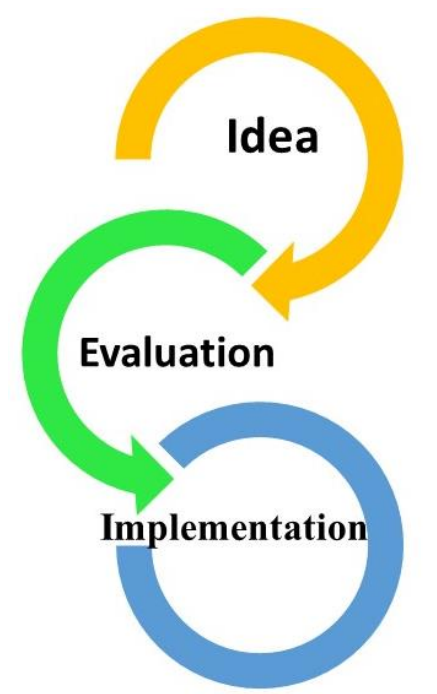

Figure 2 Idea recognition process

Developing entrepreneurship skills means exposing students to real-life business situations and risks and teaching them to analyze them.

- By encouraging participation in case studies, workshops and industry projects, students can be equipped with the knowledge to relate theoretical concepts and content with real business challenges.

- Guest lectures from industry experts and professionals can help students have an engaging industry-oriented session and add practical insight into the course content.

- Educational institutions can aid students in business/product launches by working in tandem with aspiring graduates and helping them get funds and research to build their business ideas.

- Also, international exchange programs at educational institutions expose students to varied cultures and professional backgrounds, allowing them to understand business operations from a global perspective.

\section{ReSUlt AND DiscuSSIONS}

The role of universities and their courses in building entrepreneurship skills is inevitable. Once the student has developed entrepreneurial mindset it will help him in every walk of his life. Indeed, a college/university environment can provide students with all the resources and research information to bring their ideas to life and most importantly can give access to experts in a variety of fields. Entrepreneurship curriculum should aim to bridges the gap between theory and practice. A basic knowledge of financial management along with a specialization in entrepreneurship equips and makes students ready not only for the information that pertains to launching a business but also having insight of all other necessary things required to keep the business up and running. The role of educator is to provide students with the cutting-edge of complete knowledge. The aim is to develop entrepreneurs of tomorrow with globally acceptable competence and actionable intelligence.

\section{CONCLUSION}

The role of educators and educational institutes is very important in nurturing entrepreneurial skills in students. Entrepreneurial thinking is way of living, an approach to look at the things and happens over time. Therefore, the educator needs to develop teaching models that focus on discovery, evaluation, and/or exploitation of an opportunity. Further, entrepreneurship is about value creation where the most valuable design opportunity is grounded at the overlap of customer desirability i.e. whether the customer need this? Is there any market for the product, is technology existing to achieve the proposed idea, and business viability, whether one should go ahead with the proposition. 


\section{ACKNOWLEDGEMENT}

We owe our sincere feelings of gratitude to MIT Group of Institutions, Moradabad. We are also thankful to Prof. B.P. Singh, Director MIT \& Prof. R. Yadav, former Director General MIT for their support, guidance and suggestions, which helped us a lot to write the paper.

\section{REFERENCES}

[1]. K.Shinghal, A. Saxena, "Effective Entrepreneurship Education through Teaching Case", International Journal of Engineering Sciences \& Emerging Technologies, Volume 10, Issue 3, pp: 82-84, Mar. 2018.

[2]. K.Shinghal, A. Saxena, "Developing Entrepreneurial Mindset in Engineers", International Journal of Scientific Research and Management Studies (IJSRMS), Volume 4 Issue 2, pp. 56-59, Sept. 2017.

[3]. Astri Ghina, Togar M. Simatupang and Aurik Gustomo (June 7th 2017). Entrepreneurship Education within Higher Education Institutions (HEIs), Global Voices in Higher Education, Susan L. Renes, IntechOpen, DOI: 10.5772/intechopen.69043

[4]. T. Yamamoto, M. Okunuki, K. Manabe, Wen-Chi, V. Wu and A. Y. H. Liao, "The incubator course for the global learning environment from the KU campus to Asian universities - Active learning in action: A Team-Based PBL Online Interactive course proposal for Asian universities: Bridging societies and universities," 2017 10th International Conference on Ubi-media Computing and Workshops (UbiMedia), Pattaya, 2017, pp. 1-4.

[5]. S.Santhana Jeyalakshmi, "Role of Higher Education in Promoting Entrepreneurship", Shanlax International Journal of Management, Vol. 3 No. 1, pp70-77, July 2015.

[6]. Anis ur Rehman, Dr. Yasir Arafat Elahi, "Entrepreneurship Education in India - Scope, challenges and Role of B-schools in Promoting Entrepreneurship Education”, International Journal of Engineering and Management Research, Vol. 2, Issue-5, pp. 5-14, October 2012.

[7]. K. J. Reid and D. M. Ferguson, "Work in progress - Measuring and enhancing the entrepreneurial mindset of freshman engineering students," 2010 IEEE Frontiers in Education Conference (FIE), Washington, DC, 2010, pp. F2C-1-F2C-2.

\section{AUTHORS BIOGRAPHY}

Kshitij Shinghal has 18 Years of experience in the field of Academic and is actively involved in research \& development activities. He obtained his Doctorate degree from Shobhit University Meerut in 2013, Masters degree (Digital Communication) in 2006 from UPTU, Lucknow. He started his career from MIT, Moradabad. Presently he is working as an Associate Professor, Deptt of E\&C Engg., at MIT Moradabad. He has published number of papers in national journals, conferences and seminars. He has guided two Masters, more than sixty students of B. Tech, and guiding three Ph.D. \& M. Tech. theses. He is an active Member of Various Professional Societies such as ISTE, IACSIT, IAENG etc.

Amit Saxena has 13 Years of experience in the field of Academic. He obtained his Bachelor's degree in Electronics \& Communication Engineering from I.E.T., Rohilkhand University, Bareilly and Masters degree (VLSI Design) in 2009 from UPTU, Lucknow. He started his career from MIT, Moradabad. Presently he is working as an Assistant Professor, Deptt of E\&C Engg., at MIT Moradabad. He has published number of papers in international \& national journals, conferences and seminars. He is an active Member of Various Professional Societies

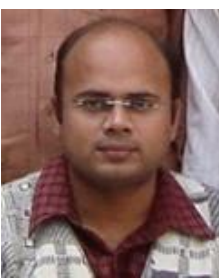
such as ISTE, IACSIT, IAENG etc. 